

\section{Kalpataru}

Jurnal Sejarah dan Pembelajaran Sejarah

Volume 7, Nomor 1, Juli 2021

\section{Chief Editor}

Drs. Sukardi, M.Pd.

\section{Editor}

Dr. Muhamad Idris, M.Pd.

Eva Dina Chairunisa, M.Pd.

Jeki Sepriady, S.Pd.

\section{Reviewer}

Dr. Tahrun, M.Pd.

Drs. Supriyanto, M.Hum.

Dra. Retno Purwati, M.Hum.

Dr. Nor Huda Ali, M.Ag., M.A.

Dr. Budi Agung Sudarman, S.S., M.Pd.

Dr. Purmansyah, M.A.
(Universitas PGRI Palembang)

(Universitas Sriwijaya Palembang)

(Balai Arkeologi Sumatera Selatan)

(Masyarakat Sejarawan Indonesia Sumsel)

(Balai Bahasa Provinsi Sumatera Selatan)

(Universitas Muhammadiyah Palembang)

\footnotetext{
Alamat Redaksi

Program Studi Pendidikan Sejarah

Fakultas Keguruan dan IImu Pendidikan Universitas PGRI Palembang

Telp. 0711-510043

Email: jurnalkalpatarusejarah@gmail.com

Website: https://jurnal.univpgri-palembang.ac.id/index.php/Kalpa
} 


\section{Kalpataru}

JURNAL SEJARAH DAN

PEMBELAJARAN SEJARAH

Terbit dua kali setahun pada Juli dan Desember

Diterbitkan oleh:

Program Studi Pendidikan Sejarah Jurusan Pendidikan IPS

Fakultas Keguruan

dan IImu Pendidikan

Universitas PGRI Palembang

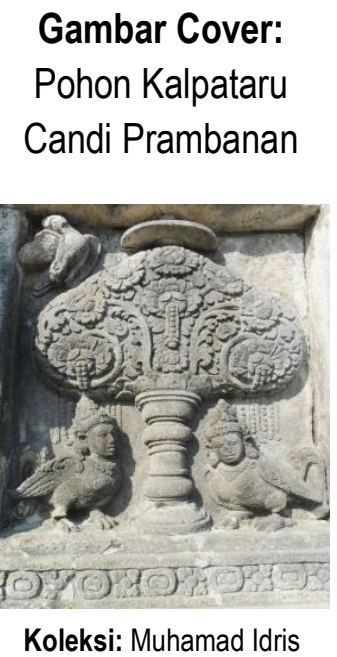

\section{DAFTAR ISI}

Nilai Budaya Masjid Jami' Sungai Lumpur Kelurahan II Ulu Palembang Sebagai Sumber Pembelajaran Sejarah Maya Susanti, Muhamad Idris, Aan Suriadi. $1-9$

Analisis Konsep Gender Dalam Undang-Undang Simbur Cahaya Sebagai Sumber Pembelajaran Sejarah Ruli Annisa, Muhamad Idris, Kabib Sholeh .... 10-18

Perbedaan Model Pembelajaran Student Teams Achievement Divisions (STAD) dengan Model Pembelajaran Jigsaw Terhadap Hasil Belajar Siswa Pada Mata Pelajaran Sejarah di SMA Negeri 2 Mesuji Taufik Sidiki Al-Haq, Nur Ahyani, Ida Suryani. 19-27

Pengaruh Pemanfaatan Media Youtube Terhadap Hasil Belajar Siswa Mata Pelajaran Sejarah di SMK PGRI 2 Palembang Riska Anggraini, Nur Ahyani, Ida Suryani. 28-36

Pengaruh Metode Pembelajaran Daring Terhadap Hasil Belajar Siswa Pada Mata Pelajaran Sejarah di Kelas XI IPA SMA Shailendra Palembang

Christina Leovita Saragih, Nur Ahyani, Aan Suriadi. $37-42$

Pengembangan Media Pembelajaran Digital Bukti-bukti Bangunan Masjid Kuno di Palembang Berbasis Android Varokah Widiyanti, Eva Dina Chairunisa, Ahmad Zamhari ..... 43-51

Hubungan Jawa-Melayu Dalam Dunia Arsitektur Melayu Sumatera Selatan

Reyvaldi Uyun, Muhamad Idris, Ahmad Zamhari $52-60$

Kondisi Politik Orde Baru di Gorontalo Tahun 19681998

Ferrari Yuliawati S, Suryo Ediyono. $61-67$

Nilai-nilai Sejarah dan Budaya Ikonografi Megalith di Lahat Sebagai Sumber Pembelajaran Sejarah Nasional Jainal Arifin, Sukardi, Dina Sri Nindiati.. 68-76

Minat Siswa Terhadap Sejarah dan Budaya Palembang di SMA Negeri 15 Palembang

Febbi Astuti, Muhamad Idris, Kabib Sholeh. 77-82 
Kalpataru, Volume 7, Nomor 1, Juli 2021 (77-82)

\title{
MINAT SISWA TERHADAP SEJARAH DAN BUDAYA PALEMBANG DI SMA NEGERI 15 PALEMBANG
}

\author{
Febbi Astuti \\ Guru di SMA Negeri 15 Palembang Palembang \\ Email: febbiastuti01@gmail.com \\ Muhamad Idris \\ Dosen Program Pendidikan Sejarah FKIP Universitas PGRI Palembang \\ Email: idrismuhamad1970@gmail.com \\ Kabib Sholeh \\ Dosen Program Pendidikan Sejarah FKIP Universitas PGRI Palembang \\ Email: habibsholeh978@gmail.com
}

\begin{abstract}
ABSTRAK
Sejarah dan budaya Palembang merupakan salah satu warisan kekayaan yang dimiliki oleh Kota Palembang, sehingga generasi remaja harus memiliki ketertarikan atau minat mempelajari sejarah dan budaya yang beragam agar sejarah dan budaya tersebut tidak hilang dimakan zaman. Permasalahan dalam penelitian ini adalah bagaimana minat siswa SMA Negeri 15 Palembang terhadap sejarah dan budaya Palembang? Tujuan penelitian ini yaitu mengetahui minat siswa SMA Negeri 15 Palembang terhadap sejarah dan budaya Palembang. Metodologi yang digunakan dalam penelitian adalah metode deskriftif kuantitatif. Teknik pengumpulan data yang digunakan adalah angket/kuisioner (google form) dan dokumentasi. Uji instrumen penelitian yang digunakan ialah uji validitas, reabilitas dan uji regresi linier sederhana. Teknik analisis data dalam penelitian ini menggunakan analisis deskriftif kuantitatif. Hasil penelitian adalah minat generasi remaja di SMA Negeri 15 Palembang pada sejarah dan budaya Palembang berada pada tingkat yang rendah. Karena dari hasil analisis data yang telah dilakukan pada 72 sampel penelitian, ditemukan bahwa hampir keseluruhan dari sampel penelitian masuk dalam kriteria cukup baik. Untuk kriteria sangat baik dan baik, itu tidak ada satupun yang masuk dalam kriteri tersebut. Sehingga dapat disimpulkan bahwa, minat siswa dalam sejarah dan budaya Palembang di SMA Negeri 15 Palembang adalah Rendah.
\end{abstract}

Kata Kunci: Minat Belajar, Sejarah Palembang, Budaya Palembang.

\section{A. PENDAHULUAN}

Pendidikan di Indonesia, diharapkan mampu membangun integritas kepribadian manusia Indonesia seutuhnya dengan mengembangkan berbagai potensi secara terpadu. Menurut Hasbullah (2015) dalam Perdana (2019:1) UU RI No. 20 Tahun 2003 tentang Sistem Pendidikan Nasional Pasal 3 menegaskan "Pendidikan Nasional berfungsi mengembangkan kemampuan dan membentuk watak serta peradaban bangsa dan bermartabat dalam rangka mencerdaskan kehidupan bangsa, bertujuan untuk perkembangan potensi peserta didik agar menjadi manusia yang beriman dan bertakwa kepada Tuhan Yang
Maha Esa, berakhlak mulia, sehat berilmu, cakap, kreatif, mandiri, dan menjadi warga negara yang demokratis serta bertangung jawab".

Guru sejarah masa kini diberikan kesempatan untuk mengembangkan materi yang mereka miliki sesuai dengan apa yang ada di wilayah sekitarnya, yaitu dengan mata pelajaran sejarah yang berfokus pada lokasi sejarah suatu daerah. Pengajaran sejarah lokal sangat mendukung usaha pengembangan kurikulum muatan lokal yang mengakrabkan siswa dengan lingkungan sekitarnya sehingga juga tentunya akan mengakomodir kebutuhan daerah. Keberhasilan belajar siswa, khususnya 


\section{Kalpataru, Volume 7, Nomor 1, Juli 2021 (77-82)}

pemahaman sejarah lokal tergantung dari dalam siswa itu sendiri dan dari luar siswa (Siska, 2017:172).

Menurut Krug (1967:22) dalam Siska berpendapat bahwa pengajaran sejarah suatu bangsa merupakan sebuah upaya terbaik untuk memperkuat antara kesatuan nasional serta dapat menanamkan semangat cinta tanah air dan jiwa patriotik kepada siswa sebagai generasi penerus bangsa. Dengan demikian, pengajaran sejarah sebagai pemahaman serta penyadaran akan membangkitkan jiwa semangat pengabdian yang tinggi dengan rasa tanggung jawab. Kesadaran siswa terhadap sejarah akan melahirkan aspirasi dan inspirasi serta partisipasi untuk melaksanakan tugasnya sebagai warga negara Indonesia yang seutuhnya (Siska, 2017:173).

Pembelajaran saat ini ialah pembelajaran yang dilakukan hanya dalam kelas yang di mana pembalajaran tersebut sangat monoton bagi siswa. Di mana pembelajaran hanya terpaku pada guru yang menjadi fokus utama para siswa. Hal demikian menyebabkan konsepkonsep pembelajaran yang kurang tepat dikarenakan tidak mengaitkan dengan sumber ilmu di lingkungan sekitar. Nilai-nilai yang dianut oleh masyarakat asli yang penuh dengan nilainilai kearifan lokal tersebut diabaikan dalam pembelajaran khususnya dalam pembelajaran sejarah. Sehingga pembelajaran di wilayah lingkungan siswa tersebut kurang mendapatkan daya tarik bagi siswa, karena siswa kurang mengetahui berbagai sejarah dan budaya lokal yang ada di sekitarnya (Jayanti, 2015:2).

Perkembangan zaman saat ini serta adanya arus globalisasi ini mengakibatkan banyak perubahan-perubahan yang terjadi di dalam pola kehidupan masyarakat, yang juga berpengaruh pada kebudayaan masyarakat itu sendiri khususnya generasi remaja. Kebudayaan yang ada di daerah peninggalan leluhur saat ini sudah mulai terpengaruh dengan kebudayaan-kebudayaan yang berasal dari luar dan lambat laun kebudayaan daerah tersebut mulai ditinggalkan. Kebudayaan daerah di Indonesia ada yang murni hasil dari karya, cipta masyarakat Indonesia sendiri dan ada yang terpengaruh dengan kebudayaan asing karena adanya komunikasi dengan kebudayaan asing pada masa lampau. Kebudayaan daerah khususnya kesenian-kesenian tradisional pada masa sekarang ini sudah mulai terpinggirkan dan digantikan oleh kesenian yang lebih modern. Masyarakat dan remaja khususnya sudah mulai terbuka dengan perkembangan yang ada karena terjadi perubahan sosial pada masyarakat, keterbukaan terhadap kebudayaan luar, serta adanya modernisasi dan globalisasi yang secara tidak sadar merubah kebudayaankebudayaan yang ada pada masyarakat dan remaja yang mulai tertarik pada budaya luar (Irhandayaningsih, 2018:21).

Pada temuan empiris serta hasil Fokus Grup Diskusi (FGD) yang berhasil disusun sebuah model pengembangan konservasi, terdapat tiga faktor yang penting untuk dikembangkan dalam meningkatkan minat terhadap sejarah dan budaya lokal. Pertama ialah lembaga, dalam hal ini yang dimaksud dengan lembaga adalah instansi pemerintah yang berwenang menangani cagar budaya yang ada di wilayah tersebut. Kedua ialah materi, maksud dari materi tersebut ialah materi yang dapat memberikan sebuah perasaan untuk menanamkan dan menjaga budaya yang ada. Ketiga lembaga non pemerintah, yang artinya ialah seluruh mayarakat yang ada di wilayah tersebut (Suharso, 2017:101).

Minat belajar merupakan salah satu faktor yang penting dalam hasil dan proses belajar seseorang (siswa). Hal tersebut dikarenakan jika seseorang (siswa) menyukai pelajaran tersebut maka dengan sendirinya akan belajar dengan sungguh-sungguh dan akan sangat senang ketika mengikutinya, sehingga mereka bisa mendapatkan hasil belajar yang sangat baik. Seseorang dengan minat belajar yang tinggi tidak akan menjadikan hambatan sebagai halangan atau kendala dalam belajar, mereka yang berminat tinggi tidak akan mengalami kendala dalam belajar di waktu kapan pun baik pagi maupun siang. Dengan kata lain, ketika seseorang memiliki minat belajar yang sangat tinggi maka mereka akan lebih bisa mengontrol dirinya sendiri, sehingga mereka dapat meningkat hasil belajar mereka. Sedangkan seseorang yang memiliki minat belajar rendah, mereka tidak bisa memotivasi dirinya sendiri untuk mendapatkan 
hasil belajar yang diharapkan (Lestari, 2013:124).

Minat belajar berperan sebagai salah satu faktor pendorong dalam hasil belajar siswa di dunia pendidikan. Minat belajar tersebut dibangun baik dari faktor eksternal atau internal siswa itu sendiri.

\section{B. METODE PENELITIAN}

Penelitian ini menggunakan metode deskriftif kuantitatif. Adapun yang menjadi variabel dalam penelitian ini yakni:

1. Variabel bebas $(X)$ : Minat siswa-siswi SMA Negeri 15 Palembang.

2. Variabel terikat $(\mathrm{Y})$ : Pembelajaran sejarah (Y1) dan budaya lokal Palembang (Y2).

\section{Populasi dan Sampel}

Populasi dalam penelitian ini ialah siswasiswi kelas X SMA Negeri 15 Palembang. Dengan sampelnya adalah siswa kelas X MIPA 1 yang berjumlah 36 siswa-siswi dan X IPS 2 yang berjumlah 36 siswa-siswi.

\section{Teknik Pengumpulan Data}

Teknik pengumpulan data dapat dilakukan dengan berbagai macam teknik yang sudah ada sesuai metode penelitian yang telah ditentukan sebelumnya. Dalam penelitian ini teknik pengumpulan data yang digunakan ialah:

Kuisioner: Metode pengumpulan data menggunakan kuesioner. Kuesioner adalah teknik pengumpulan data yang dilakukan dengan cara memberikan seperangkat pertanyaan atau pernyataan tertulis untuk memperoleh data berupa jawaban dari responden (Krisyantono, 2006:59). Dalam penelitian ini kuisioner dibuat dengan bantuan google form.

Dokumentasi: Digunakan untuk mendapatkan data yang ada di lapangan seperti arsip, foto dan dokumen yang menyimpan tentang penelitian.

\section{HASIL DAN PEMBAHASAN Hasil Penelitian}

Kuisioner yang telah dipersiapkan sebelumnya dilakukan validasi terlebih dahulu atas tiap-tiap butir pernyataan tersebut, sehingga butir-butir pernyataan tersebut dapat diandalkan dan terpercaya. Pernyataan yang telah disiapkan pada awal penelitian ialah berjumlah 45 butir, yang terdiri dari variabel $x$, $\mathrm{y} 1$ dan $\mathrm{y} 2$. Pernyataan tersebut dilakukan validasi awal kepada dosen ahli materi terlebih dahulu, setelah mendapat persetujuan dosen ahli materi, barulah kuisioner disebar untuk melakukan uji validitas dan reabilitas.

\section{Uji Validitas}

Validitas adalah suatu pengukuran yang mengacu pada proses di mana pengukuran benar-benar bebas dari kesalahan sistematis dan kesalahan random. Pengukuran yang valid berarti alat ukur yang digunakan untuk mendapatkan data itu valid nilainya. Valid di sini berarti instrumen yang digunakan nantinya untuk mengukur apa yang seharusnya diukur. Pada penelitian ini, digunakan validitas Pearson berdasarkan rumus korelasi product moment. Adapun kriteria pengujiannya adalah, Apabila

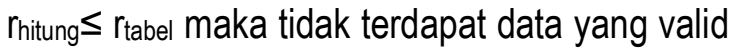
sedangkan apabila $r_{\text {hitung }} \geq$ rtabel $_{\text {ta }}$ terdapat data yang valid. Adapun rtabel yang digunakan dengan sig. $5 \%$ dengan jumlah responden 67 , sehingga $r_{\text {tabel }}$ dalam penelitian ini adalah 0,244.

Adapun hasil dari uji validitas, dengan menggunakan bantuan IBM SPSS Statistik version 25. Adapun hasil dari uji validitas ini adalah dari 45 butir pernyataan yang telah disusun sebelumnya terdapat 2 item yang tidak valid, yaitu item nomor 1 dari variabel $X$ dengan hasil rhitung adalah 0,003 dan item nomor 5 dari variabel $\mathrm{Y} 1 \mathrm{X}$ dengan hasil ritung adalah 0,103. Sehingga item yang tidak valid tersebut tidak dapat digunakan sebagai instrumen penelitian. Sedangkan 43 item yang valid yang digunakan sebagai instrumen dalam penelitian ini.

\section{Uji Reabilitas}

Reabilitas artinya memiliki sifat dapat dipercaya. Suatu alat ukur yang dipergunakan harusnya dapat memberikan hasil yang relatif sama apabila dilakukan pengukuran kembali terhadap subyek yang sama. Suatu instrumen yang mempunyai relabilitas yang tinggi menunjukkan bahwa instrumen tersebut stabil (tidak berubah-ubah), konsisten, dan dependabilitas (dapat diandalkan). 
Dalam uji reabilitas, alternatif jawaban lebih dari dua menggunkan Cronbach's Alpha, yang dibandingkan dengan nilai koefisien reabilitas minimal yang dapat diterima. Jika nilai Cronbach's Alpha >0.6, maka instrumen penelitian reliabel. Jika nilai Cronbach's Alpha $<0.6$, maka instrumen penelitian tidak reliabel.

Adapun uji reabilitas dapat dilakukan dengan menggunakan IBM SPSS Statistik version 25 , hasil dari uji reabilitas instrumen penelitian ini ialah dapat dilihat pada tabel sebagai berikut:

Tabel 1

Hasil Uji Reabilitas

\begin{tabular}{|c|c|}
\hline \multicolumn{2}{|c|}{ Reliability Statistics } \\
\hline Cronbach's Alpha & N of Items \\
\hline, 882 & 45 \\
\hline Sumber: Pengolahan data IMB SPSS Statistik Versi 25
\end{tabular}

Berdasarkan pada tabel $1 \mathrm{di}$ atas, hasil uji reabilitas tentang minat siswa terhadap sejarah dan budaya Palembang dengan Crocnbach's Alpha yang menunjukkan bahwa angket minat riliabel, karena $0,882>0.6$.

\section{Hasil Analisis Data Angket Penelitian}

Pembagian atau penyebaran angket dilakukan pada 2 kelas yang dijadikan sampel dalam penelitian ini, ialah kelas X MIPA 1 dan X IPS 2. Penyebaran tautan kuisioner telah disampaikan oleh peneliti kepada Guru Bidang Wakil Kurikulum SMA Negeri 15 Palembang, tautan itu peneliti bagikan pada tanggal 09 Juni 2021. Adapun seluruh siswa, baik kelas X MIPA 1 maupun siswa kelas $X$ IPS 2 seluruhnya mengisi kuisioner tersebut. Sehingga peneliti bisa melakukan analisis data dari hasil tanggapan responden tersebut, untuk menentukan apakah tingkat minat siswa terhadap sejarah dan budaya Palembang berada pada interval sangat baik, baik, cukup baik, atau tidak baik.

Adapun hasil olah data yang telah peneliti lakukan dengan menggunakan rumus statistika menggunakan program excel, serta telah dilakukan analisis data dari hasil olahan data tersebut. Maka dapat diklasifikasikan mengenai minat siswa, apakah berada pada kriteria sangat baik, baik, cukup baik, atau tidak baik. Tabel rentang presentase tersebut dapat dilihat pada tabel berikut:

Tabel 2

Analisis Deskriptif

\begin{tabular}{|c|c|c|}
\hline No & $\begin{array}{c}\text { Rentang } \\
\text { Persentase }\end{array}$ & Kriteria \\
\hline 1 & $>81,25 \%-100 \%$ & Sangat Baik \\
\hline 2 & $>62,25 \%-81,25 \%$ & Baik \\
\hline 3 & $>43,75 \%-62,25 \%$ & Cukup Baik \\
\hline 4 & $>25 \%-43,75 \%$ & Tidak Baik \\
\hline \multicolumn{3}{|c|}{ Sumber: (Riduwan, 2009:53-156). }
\end{tabular}

Pada pengolahan data analisis kelas $X$ MIPA 1 , terdapat 36 responden siswa yang memberikan tanggapan terhadap kuisioner minat siswa tersebut.

Berdasarkan hasil jawaban responden dan hasil olah data dan analisis data, didapatkan berbagai macam rentang presentase (skor) yang didapatkan oleh 36 responden di kelas ini. Pada bagian kriteria, hanya terdapat dua macam kriteria yang ada di kelas ini. Kriteria yang pertama ialah kriteria cukup baik, dengan rentang analisis presentase $>43,75 \%$ - 62,25\%. Dalam kriteria ini, sebanyak 26 responden siswa masuk dalam kategori cukup baik. Sedangkan dalam rentang presentase $>25 \%-43,75 \%$ yang digunakan untuk menunjukan kriteria tidak baik ialah sebanyak 10 orang siswa, adapun rata-rata keseluruhan dikelas X MIPA 1 adalah 45,74\%.

Selanjutnya ialah analisis data yang dilakukan di kelas X IPS 2. Pengolahan data dalam analisis kelas ini juga menggunakan rumus statistika pada excel. Dalam pengelolaan hasil jawaban dari kuisioner kelas X IPS 2, terdapat 36 siswa yang memberikan jawabannya.

Berdasarkan hasil olah data dan analisis data didapatkan hasil bahwa hampir dari 36 siswa yang menjadi sampel tidak ada yang mendapatkan kriteria sangat baik atau baik. Dalam hasil olah data kelas X IPS 2 ini berbeda dengan hasil analisis data pada kelas X MIPA 1, karena dalam hasil akhir yang didapatkan oleh kelas X IPS 2 ialah berada pada kriteria cukup baik dengan rentang analisis presentase $>43,75 \%$ - $62,25 \%$, dengan rata-rata skor keseluruhan ialah $48,32 \%$. 


\section{Pembahasan}

Berdasarkan hasil analisis data, dapat diketahui bahwa ketertarikat atau minat generasi remaja pada sejarah dan budaya daerah di sekitarnya berada pada tingkat yang rendah. Karena dari hasil analisis data yang telah dilakukan pada 72 sampel penelitian, ditemukan bahwa hampir keseluruhan dari sampel penelitian masuk dalam kriteria cukup baik. Untuk kriteria sangat baik dan baik, itu tidak ada satu pun yang masuk dalam kriteria tersebut. Sehingga dapat disimpulkan bahwa, minat siswa dalam sejarah dan budaya Palembang di SMA Negeri 15 Palembang adalah Rendah.

Perbedaan antara hasil akhir di kelas MIPA dan IPS cukup terlihat jelas, karena dalam hasil analisis data yang peneliti lakukan hasilnya adalah keseluruhan hasil yang ada pada kelas X IPS seluruh sampel dalam kelas IPS ini masuk dalam kriteria yang cukup baik. Sedangkan dalam kelas X MIPA hanya beberapa persen saja yang masuk dalam kriteria tidak baik. Penyebab perbedaan perolehan akhir antara MIPA dan IPS bisa saja disebabkan oleh perbedaan materi pelajaran pada Kurikulum 2013 antara MIPA dan IPS yang dibagi menjadi sejarah wajib dan sejarah peminatan.

Rendahnya minat tersebut disebabkan oleh beberapa faktor, di antaranya ialah siswa itu sendiri kurang memahami tentang sejarah dan budaya Palembang, serta kurangnya peran lingkungan sekitar. Dimaksud lingkungan sekitar ialah peran guru dan pemerintah dalam memberikan atau menyediakan informasi dan sumber pengetahuan bagi siswa dalam mencari sumber ilmu mengenai sejarah dan budaya di sekitanya, kekurangan sumber pengetahuan membuat minat belajar menjadi kurang.

\section{SIMPULAN}

Berdasarkan hasil analisis data dan pembahasan, dapat disimpulkan bahwa minat siswa terhadap sejarah dan budaya Palembang yang dilakukan dalam penelitian di SMA Negeri 15 Palembang. Dengan sampel kelas X MIPA 1 dan X IPS 2, berada pada kategori rendah. Hal tersebut bisa dilihat dari kriteria yang paling banyak didapatkan dalam hasil penelitian ini kriteria cukup baik, dengan rentang persentase
$>43,75 \%-62,25 \%$. Bisa dikatakan dari 100\% sampel yang diteliti, yang memiliki nilai cukup baik ialah $85 \%$.

Pada kelas X IPS 2, keseluruhan sampel responden mendapatkan hasil dalam kriteria yang cukup baik. Sedangkan dalam sampel kelas X MIPA 1, lebih dari setengah sampel yang masuk dalam kriteria cukup baik. Perbedaan pencapaian yang dimiliki oleh kedua kelas tersebut mungkin saja dipengaruhi oleh jurusan dan fokus materi pembelajaran yang dimiliki kedua kelas ini berbeda, antata ilmu pengetahuan dan ilmu sosial. Perbedaan tersebut juga dapat disebabkan oleh perubahan kurikulum saat ini, yaitu Kurikulum 2013 yang membuat pelajaran sejarah dibagi menjadi sejarah peminatan dan sejarah wajib.

Rendahnya minat tersebut berdasarkan beberapa faktor, seperti kurangnya rasa ingin tau, pengaruh dan perkembangan budaya luar yang semakin pesat, khususnya mencari sumber tentang budaya dan sejarah lokal Palembang serta kurangnya peran guru dan pemerintah dalam meningkatkan sejarah dan budaya lokal Palembang. Sehingga generasi remaja saat ini kurang tertarik pada kebudayaan di sekitarnya, dan kurangnya minat ini akan menyebabkan kebudayaan yang sudah ada lambat kaun akan hilang.

\section{DAFTAR PUSTAKA}

Irhandayaningsih, A. 2018. "Pelestarian Kesenian Tradisional sebagai Upaya dalam Menumbuhkan Kecintaan Budaya Lokal di Masyarakat Jurang Blimbing Tembalang. Dalam Anuva. 2, 21.

Jayanti, E. 2015. Penerapan Pembelajaran Berbasis Budaya Lokal Mapag Dewi Sri untuk Meningkatkan Keterampilan Berpikir Kritis Siswa pada Konsep Ekosistem di MAN Cirebon 1. Dalam IAIN Syekh Nurjati Cirebon. 2.

Krisyantono, R. 2006. Teknik Praktis Riset Komunikasi Didertai Contoh Praktis Riset Media, Public Relation, Advertaising, Komunikasi Organisasi, Komunikasi Pemasaran. Jakarta: Kencana. 
Lestari, I. 2013. "Pengaruh Waktu Belajar dan Minat Belajar terhadap Hasil Belajar Matematika". Dalam Jurnal Formatif. 3 (2). 124.

Perdana, M. R. 2019. Pengembangan Media Peta dalam Bentuk Puzzel dengan Memanfaatkan Plastik Kemasan Makanan Ringan pada Mata Pelajaran Sejarah. Palembang: Universitas PGRI Palembang. (Skripsi).

Riduwan. 2009. Metode dan Teknik Penyusunan Proposal Penelitian. Bandung: Alfabeta.

Siska, Y. 2017. "Hubungan Minat Belajar dengan Pemahaman Sejarah Lokal Lampung pada Siswa Kelas V Sekolah Dasar di Bandar Lampung". Dalam Pendidikan dan Pembelajaran Dasar. 4. 172.

Suharso, R. 2017. "Pembelajaran Sejarah Lokal pada Kelas Sejarah (Model Pengembangan Bahan Ajar Sejarah Lokal Kota Kudus dalam Rangka Meningkatkan Minat Siswa pada Sejarah)". Dalam Sejarah dan Budaya. 101. 


\section{KETENTUAN PENULISAN ARTIKEL JURNAL KALPATARU}

1. Naskah berbahasa Indonesia yang disempurnakan bertemakan kesejarah yang meliputi hasil penelitian sejarah, pengajaran sejarah dan penelitian kebudayaan.

2. Naskah harus asli dan belum pernah dimuat dalam media lain. Naskah dapat berupa hasil penelitian/artikel kajian konseptual yang ditulis oleh perorangan dan atau kelompok.

3. Naskah ditulis dengan cara-cara yang sesuai dengan ketentuan penulisan artikel ilmiah menggunakan bahasa Indonesia yang baku, berupa ketikan, beserta soft file dalam CD-RW atau dengan mengirimkan email pada redaksi jurnal Kalpataru dengan alamat jurnalkalpatarusejarah@gmail.com, spasi tunggal, jenis huruf arial narrow ukuran 12, dengan panjang naskah antara 8-15 halaman pada kertas A4.

4. Artikel hasil penelitian memuat:

JUDUL

Nama Penulis

Abstrak

A. PENDAHULUAN

B. METODE PENELITIAN

C. HASIL DAN PEMBAHASAN

D. SIMPULAN

DAFTAR PUSTAKA
: XXX (HURUF KAPITAL)

: (disertai jabatan, institusi, dan email)

: (Bahasa Indonesia yang memuat 100-200 kata diikuti kata kunci, dengan jenis huruf arrial narrow dan ukuran huruf 11 serta dicetak miring).

: (memuat latar belakang masalah, tinjauan pustaka secara ringkas, masalah penelitian, dan tujuan penelitian).

5. Artikel Kajian Konseptual memuat:

JUDUL

Nama Penulis

Abstrak

PENDAHULUAN

Sub Judul

Simpulan

DAFTAR PUSTAKA
: (berisi simpulan).

: (berisi pustaka yang dirujuk dalam uraian naskah).

6. Referensi sumber dalam teks artikel ditulis dengan menggunakan side note, contoh (Jalaludin, 1991:79); sementara penulisan daftar pustaka disusun dengan ketentuan. Nama pengarang. Tahun terbit. Judul (dicetak miring). Kota terbit: Nama Penerbit. Contoh: Koentjaraningrat. 2010. Manusia dan Kebudayaan di Indonesia. Jakarta: Djambatan. Daftar pustaka hanya memuat pustaka/sumber yang dirujuk dalam uraian dan disusun menurut abjad tanpa nomor urut.

7. Naskah yang dimuat akan disunting kembali oleh redaksi tanpa mengubah isinya.

8. Naskah yang ditolak (tidak bisa dimuat) akan dikirim kembali ke penulis dengan pemberitahuan tertulis dari redaksi atau melalui email.

9. Penulis yang naskahnya dimuat akan mendapat 1 (satu) majalah nomor yang bersangkutan.

10. Kontak person: Muhamad Idris (081271498618); Eva Dina Chairunisa (082281267851); Jeki Sepriady (085269261780). 